Proceedings

\title{
Framework Specifications for Evaluation of Quality Improvement and Sustainable Development in Healthcare Facilities ${ }^{\dagger}$
}

\author{
Flaviu Moldovan \\ "George Emil Palade" University of Medicine, Pharmacy, Science, and Technology of Târgu Mureș, \\ Doctoral School, 540139 Târgu Mureș, Romania; moldovan.flaviu95@yahoo.com; Tel.: +40-754-671-886 \\ + Presented at the 14th International Conference on Interdisciplinarity in Engineering-INTER-ENG 2020, \\ Târgu Mures, Romania, 8-9 October 2020.
}

Published: 14 December 2020

\begin{abstract}
The purpose of this paper is to establish the specifications of an analysis and evaluation model in the form of a reference framework for the design, development, implementation, periodic evaluation, and continuous improvement of quality management systems based on the application of national and international standards for sustainable development in healthcare facilities. It integrates the existing legal requirements, standards, and quality assessment indicators from actual frameworks. Its structure is based upon the Plan-Do-Check-Act quality cycle, on the three pillars of sustainable development-social, economic, and environmental—incorporated in the seven basic topics of social responsibility mentioned in $\mathrm{ISO} 26000$.
\end{abstract}

Keywords: healthcare facility; quality improvement; sustainable development; reference framework

\section{Introduction}

A lot of research has been performed on quality improvement methods over the last decade, which developed a wide range of evaluation instruments, statistical tools, and methods of improvement. There are a large number of clinical and non-clinical interventions that have the effect of improving the quality of care. However, this reality is inconsistent with the continuous variations in quality and safety, which are constantly reported by media and scientific literature. For quality professionals that are responsible for planning, implementing, maintaining, and control of quality management in healthcare facilities at the organizational level, the abundance of information on quality and safety approaches is a complication.

The large number of quality improvement interventions is overwhelmingly high. The main decision is: what to begin with, but also how to integrate a multitude of tools into a coherent approach?

The motivation of this research is to support the management of health units in the alignment and use of these strategies and tools. Importance is accorded on cross-cutting matters such as supervision and guidance, the construction of assistance systems for quality improvement, and the provision of the adequate resources assuring high quality care. Healthcare specialists, quality professionals, and general managers can use this approach to periodically assess and continually improve the quality of their organization.

The general objective of the research is to establish the specifications of an analysis and evaluation model in the form of a reference framework for the design, development, and implementation, periodic evaluation, and continuous improvement of quality management systems based on the application of national and international standards for sustainable development in healthcare facilities. 


\section{Materials and Methods}

The research methodology considers the study of the specialized literature, relevant for the research topic, which allows the creation of an adequate framework for the development of the empirical study.

The foundations of high quality healthcare systems must include: (a) a population and their health needs and expectations,(b) the governance of the health sector, and (c) partnerships between sectors, healthcare platforms, the number and skills of the workforce involved, as well as the tools and resources used, from medicines to data. High quality healthcare systems should adopt four values:

(a) Be for people;

(b) Be fair;

(c) Resilient; and

(d) Efficient.

Sustainability can be considered an area of the quality of healthcare, extending the responsibility of health services provided to patients from now to the future. A sustainable approach extends the definition of the value of healthcare to measure healthcare outcomes in terms of social and environmental impact, but also in terms of financial costs. Mortimer et al. [1] established a practical framework for including these new dimensions in an already well-defined quality improvement model. The current trend is to collaborate between actors involved in healthcare, called collaborative healthcare, which has the capacity to address challenges such as improving the social sustainability of the system. Maghsoudi et al. [2] developed a new model of medical organization in which collaboration between medical networks plays a central role in improving social sustainability.

Improving quality can promote the association between health security and healthcare systems; through integration of quality improvement approaches addresses global health security priorities and has the effect of improving health results at in all structures of the healthcare system [3]. Marimuthu et al. [4] explores the scope of sustainability practices in healthcare by highlighting three main conceptual aspects: the dimensions of sustainability practices in healthcare, the drivers of sustainable health practices, and strategies for implementing sustainability effectively in healthcare. Smith [5] highlights three levels of sustainability in which he describes the levels of healthcare with the appropriate measurement of performance through audit techniques.

Pantzartzis et al. [6] highlight issues that can lead to small sustainable health institutions, such as energy saving and efficiency, that could be used to assess the viability of healthcare facilities. In a study, Glasgow [7] identified 539 potential articles on quality improvement methodologies and found that the true impact of this approach is difficult to assess, given that the lack of a rigorous evaluation or clearly supported improvements offers little evidence supporting widespread adoption. There is still a need for future research to improve the evidence base to understand more.

Currently, health facilities face major challenges, as patients demand continuous improvement in the quality of care, and health insurance companies demand the lowest possible prices. There are quality improvement programs from the industry, such as lean manufacturing, which is an excellent tool to meet current health challenges [8]. Some hospitals tend to adopt lean quality improvement programs, which require a lean assessment from a much more critical perspective [9] and quantification of sustainability effects [10]. A theoretical framework for sustainable health improvement developed by Hovlid et al. [11] is based on four main themes: (a) the question, (b) the decision, (c) the relationship, and $(\mathrm{d})$ the interpretation.

In Romania, the national legislation on quality assurance in health has important references: Law no. 185/2017 on quality assurance in the healthcare system [12]; Standards, procedure, and methodology for evaluation and accreditation of hospitals [13]; and Legislation on the functioning [13] and working tools [14] used by the National Authority for Quality Management in Health. Hospital accreditation standards [15] comprise threereferences: Strategic and organizational management; Clinical management; Medical ethics and patient rights, which are supplemented by 64 checklists. 


\section{Results}

This research proposes the development of a SANitary Quality (SANQ) reference framework containing a series of indicators addressed to health units that have implemented/are implementing quality management systems in their organizations and want to continuously improve the effectiveness of the quality management system by establishing quality indicators to monitor and promote their sustainable development. The conceptual model of the SANQ reference framework is presented in Figure 1, which integrates the existing legal requirements, standards, and quality assessment indicators from actual frameworks.

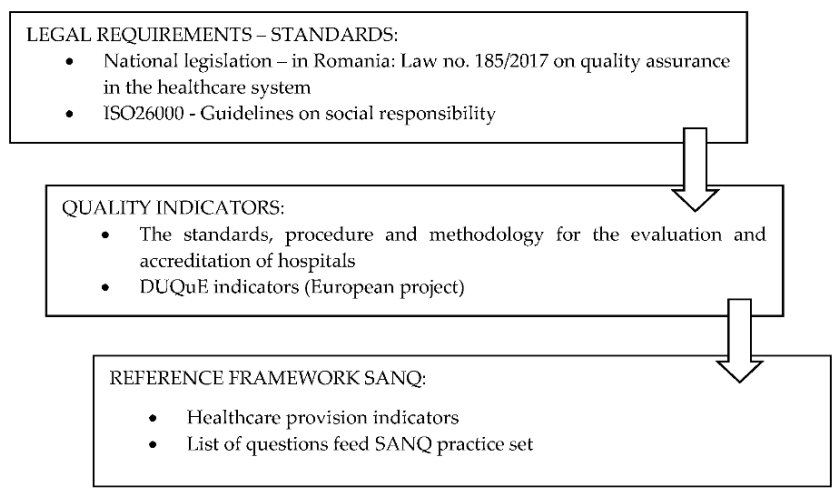

Figure 1. SANQ framework conceptual model.

In terms of quality cycle references, and in order to simplify its relationship with the already developed quality frameworks, the SANQ quality reference framework has to be structured based upon the Plan-Do-Check-Act (PDCA) quality cycle: planning, implementing, evaluating, and review. It should be developed also taking into consideration that the healthcare system can and should have a key role in the promotion of social cohesion and should also pursue financial sustainability and environmental responsibility.

The reason to adopt this conceptual model lies on the principles stated in ISO 26000, in regards to the definition of sustainable development and social responsibility — sustainable development is the "development that meets the needs of the present without compromising the ability of future generations to meet their own needs" [16]. Social responsibility is "the responsibility of an organization for the impacts of its decisions and activities on society and the environment, through transparent and ethical behavior that: contributes to sustainable development, including health and the welfare of society; takes into account the expectations of stakeholders; is in compliance with applicable law and consistent with international norms of behavior; and is integrated throughout the organization and practiced in its relationships" [17].

For this reason, the SANQ reference framework has to be structured on the threepillars of sustainable development_-social, economic, and environmental—incorporated in the seven basic topics of social responsibility mentioned in ISO26000—Guidelines on social responsibility [17], adapted to the context of healthcare provision: Organizational governance, Human rights, Labor practices, Environment, Fair operating practices, Consumer issues, Community involvement and development, as shown in Figure 2.

In this way, the SANQ quality reference framework will be structured in four main phases, each of them corresponding to the four phases of the PDCA quality cycle, regarding healthcare: design of healthcare services, provision of healthcare services, evaluation of healthcare services, continuous improvement.

The extended applicability of the reference framework requires a correspondence between the SANQ indicators and the Standards for the evaluation and accreditation of hospitals provided in Order no. 446/2017 issued by the Ministry of Health [13]. 


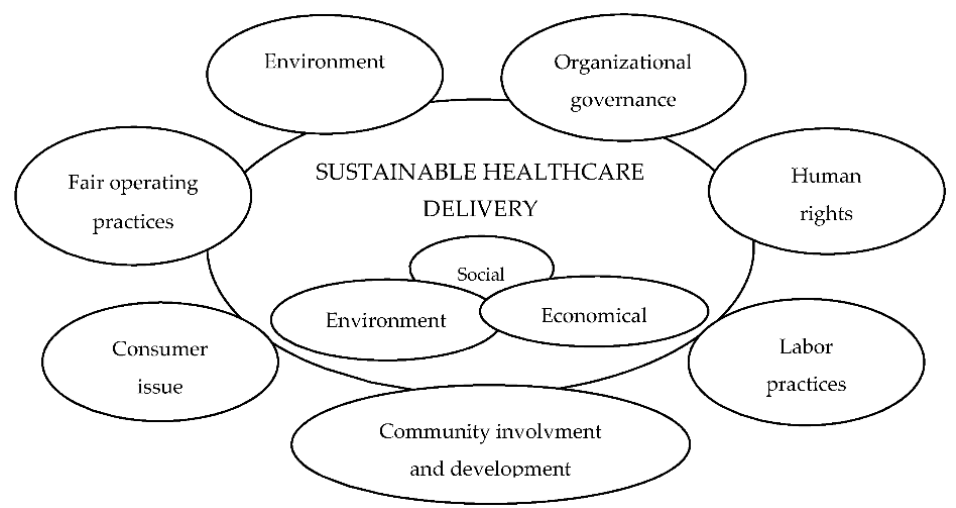

Figure 2. Pillars of sustainable development and ISO 26000 social responsibility core subjects.

The reference framework should consist of several matrix assessment tools that will be structured in line with the DUQuE project results [18]: (1) Accreditation of healthcare services, (2) The effectiveness of the organization's management, (3) Continuing medical education, (4) Patient safety culture, (5) Computerized support systems for clinical decisions, (6) Dissemination and implementation of guidelines, (7) Actions to improve transfers, (8) Patient-centered care actions, (9) Six Sigma and Lean, (10) Performance information, (11) Audit and feedback, (12) Reporting incidents to the hospital, (13) Safety checklists, (14) Documentation internships etc.

SANQ evaluation indicators are of a qualitative and/or quantitative type-which are described by formulas.

The SANQ quality reference framework will be accompanied by the Implementation Guide-The self-assessment tool, which will have threeparts: (1) The SANQ reference framework, (2) The self-diagnosis tool, (3) The implementation guide.

The self-diagnosis tool will consist of a system of questions derived from the SANQ reference framework, whose assessment is made on the basis of a qualitative (poor to excellent) and/or quantitative grid (0 to 3 points). It will facilitate easy use by quality professionals in healthcare facilities.

\section{Conclusions}

This research provided the specifications for a reference framework that aims to evaluate and improve quality and safety in healthcare facilities. The elaboration of the indicators of the reference framework requires state-of-the-art research, the use of the results of large-scale scientific studies, systematic reviews, and specialized knowledge.

Such research does not cover all quality strategies, but rather provides a perspective to support managers in reflecting on organization-wide approaches to ensure quality, safety, and sustainable development.

The widespread use of the assessment tool requires interactive links to specific assessment tools from the literature as well as those generated in this research.

Conflicts of Interest: The author declares no conflict of interest.

\section{References}

1. Mortimer, F.; Isherwood, J.; Wilkinson, A.; Vaux, E. Sustainability in quality improvement: Redefining value. Future Healthc. J. 2018, 5, 88-93. [CrossRef] [PubMed]

2. Maghsoudi, T.; Cascon-Pereira, R.; HernandezLara, A.B. TheRole of Collaborative Health care in Improving Social Sustainability: A Conceptual Framework. Sustainability 2020, 12, 3195. [CrossRef]

3. Mensah, A.N.; Syed, S.B.; Hirschhorn, L.R.; Nambiar, B.; Iqbal, U.; Garcia-Elorrio, E.; Chattu, V.K.; Devnani, M.; Kelley, E. Quality improvement and emerging global health priorities. Int. J. Qual. Health Care 2018, 30, 5-9. [CrossRef] [PubMed] 
4. Marimuthu, M.; Paulose, H. Emergence of Sustainability Based Approaches in Health care: Expanding Research and Practice. Procedia Soc. Behav. Sci. 2016, 224, 554-561. [CrossRef]

5. Smith, M.E. Sustainable Healthcare. A path to sustainability. Master'sThesis, Policy \& Management Lund University, Lund, Sweden, 2012. Available online: https://lup.lub.lu.se/luur/download?fileOId=3126182\& func $=$ downloadFile\&recordOId $=3126175$ (accessed on 17 August 2020).

6. Pantzartzis, E.; Edum-Fotwe, F.T.; Price, A.D.F. Sustainable health care facilities: Reconciling bed capacity and local needs. Int. J. Sustain. Built Environ. 2017, 6, 54-68. [CrossRef]

7. Glasgow, J.M. Guiding In patient Quality Improvement: A Systematic Review of Lean and Six Sigma. Jt. Comm. J. Qual. Patient Saf. 2010, 36, 533-540. [PubMed]

8. Van Den Heuvel, J.; Does, R.J.M.M.; DeKoning, H. Lean Six Sigma in aHospital. Int. J. Six Sigma Compet. Advant. 2006, 2, 377-388. [CrossRef]

9. De BrandaoSouza, L. Trends and Approaches in Lean Healthcare. Leadersh. Health Serv. 2009, 22, 121-139. [CrossRef]

10. Kruk, M.E.; Gage, A.D.; Arsenault, C.; Jordan, K.; Leslie, H.H.; Roder-DeWan, S.; Adeyi, O.; Barker, P.; Daelmans, B.; Doubova, S.V.; et al. High-quality health systems in the Sustainable Development Goals era: Time for a revolution. Lancet Glob. Health 2018, 6, e1196-e1252. [CrossRef]

11. Hovlid, E.; Bukve, O.; Haug, K.; Aslaksen, A.B.; von Plessen, C. Sustainability of Health care Improvement: What Can We Learn from Learning Theory? BMC Health Serv. Res. 2012, 12, 235. [CrossRef]

12. Legea, nr. 185/2017 privind asigurarea calitătii în sistemul de sănătate (Law no. 185/2017 on Quality Assurance in the Health System). Available online: http://www.spitalvn.ro/documente/legislatie/legea_185_2017.pdf (accessed on 17 August 2020).

13. Standardele, procedura şi metodologia de evaluare şi acreditare a spitalelor, aprobate prin Ordinul ministrului sănătății nr. 446/2017 (The standards, procedure and methodology for the evaluation and accreditation of hospitals, approved by the Order of the Minister of Health no. 446/2017). Available online: https://anmcs.gov. ro/web/wp-content/uploads/2017/04/OrdinMS-446-2017-StandardeEd.II_.pdf (accessed on 17 August 2020).

14. Hotărârea Guvernului nr. Hotărârea Guvernului nr. 629/2015 privind componenţa, atribuţiile, modul de organizare şi funcţionare ale Autorităţii Naţionale de Management al Calităţii în Sănătate (Government Decision no. 629/2015 on the composition, attributions, organization and functioning of the National Authority for Quality Management in Health). Available online: https://lege5.ro/Gratuit/g42donrzg4/hotararea-nr-629-2015-privind-componentaatributiile-modul-de-organizare-si-functionare-ale-autoritatii-nationale-de-management-al-calitatii-insanatate (accessed on 17 August 2020).

15. Ordinul nr. 35 din data de 20.02.2018 pentru modificarea Ordinului Președintelui Autorității Naționale de Management al Calități în Sănătate nr. 8/2018 privind aprobarea instrumentelor de lucru utilizate de către Autoritatea Naţională de Management al Calităţii în Sănătate în cadrul celui de al II-lea Ciclu de acreditare a spitalelor (Order no. 35 of 20.02.2018 for the amendment of the Order of the President of the National Authority for Quality Management in Health no. 8/2018 on the approval of the working tools used by the National Authority for Quality Management in Health within the Second Cycle of Hospital Accreditation). Available online: https://anmcs.gov.ro/web/2018/02/20/ (accessed on 17 August 2020).

16. Shah, M.M. Sustainabled evelopment. In Encyclopedia of Ecology; Jorgensen, S.E., Fath, B.D., Eds.; Imprint Elsevier Science: Philadelphia, PA, USA, 2008; pp. 3443-3446.

17. ISO26000-Guidelines on Social Responsibility. Available online: https://www.iso.org/iso-26000-socialresponsibility.html (accessed on 17 August 2020).

18. Groene, O.; Kringos, D.; Sunol, R.; on behalf of the DUQuE Project. Seven ways to improve quality and safety in hospitals. An evidence-based guide. DUQuE Collab. 2014. Available online: http://www.duque.eu/ uploads/DUQuE_Seven_Ways_To_Improve_Quality_And_Safety_2014.pdf (accessed on 17 August 2020).

Publisher's Note: MDPI stays neutral with regard to jurisdictional claims in published maps and institutional affiliations.

(C) 2020 by the author. Licensee MDPI, Basel, Switzerland. This article is an open access article distributed under the terms and conditions of the Creative Commons Attribution (CC BY) license (http://creativecommons.org/licenses/by/4.0/). 